\title{
Education, Working Group Activities and Pedagogic Competencies Their Effect on Teacher Professionalism
}

\author{
Endah Karuniawati \\ Social Studies Education \\ Universitas PGRI Kanjuruhan Malang \\ Malang, Indonesia
}

\author{
Sri Rahayu*, Iskandar Ladamay \\ Elementary School Teacher Education Study Program \\ Universitas PGRI Kanjuruhan Malang \\ Malang, Indonesia \\ *srisk@unikama.ac.id, ladamay@unikama.ac.id
}

\begin{abstract}
The role of teachers in realizing the ideals of the nation, that is to educate the community, must be supported by professional quality teachers. Teacher professionalism is influenced by a number of factors. This study aims at explaining the effect of educational background, Teacher Working Group activities and teacher pedagogical competence on teacher professionalism. This research was a correlational study with a quantitative approach. Data collection was done by using a questionnaire or questionnaire technique. Respondents in this study were 53 teachers of SDN Gugus 3, Dampit District, Malang Regency. Analysis of research data was using multiple linear regression analysis techniques, hypothesis testing using partial significance test (t test). The results showed that educational background had a positive effect on teacher professionalism with a t-count of 0.355 and a significance level of 0.000 . Teacher Working Group activities have a positive effect on teacher professionalism with a $t$ count of 0.288 and a significance level of 0.000. Pedagogic competence has a positive effect on teacher professionalism with a $t$ count of 0.339 and a significance level of 0.000. The implication of this research is that increasing teacher professionalism and competence can be achieved through formal education and KKG activities.
\end{abstract}

Keywords-education, working group activities, pedagogical competencies, teacher professionalism

\section{INTRODUCTION}

It is not an easy work to be a teacher. The mastery of the subject and its application to the students cannot be classified as a skilled teacher. Teachers who are competent in the conduct of learning activities can have an impact on student achievement. As a competent teacher, the teacher must be able to guide students to master higher-level thought skills, integrate knowledge and actively engage students in learning [1]. Teachers play an important role in the teaching and learning phase in developing students' skills [2]

Therefore, most of the literature requires teachers to demonstrate good professionalism, be actively involved in professional development, acquire knowledge of current issues, carry out assignments ethically, and demonstrate commitment and responsibility in teaching in schools [3]. However, based on a report by the United Nation Development Program (UNDP), Indonesia is still ranked 124th out of 187 countries for the human development index [4]. Studies on general competence, many teachers in Indonesia reported by the World Bank show that their level of education is still lower than a bachelor's degree [5]. Indonesian Ministry of Education data explains that teachers have low pedagogical skills, besides that the serious concern of Indonesian teachers is the low level of knowledge, skills, motivation and professional efforts [6].

A teacher's professional skill can't unexpectedly be attained by the teacher, but must be followed through different forms of continuous and systematic efforts. One of the attempts that many teachers have made to promote their professional skills is through formal education. The higher level of teachers' education and educational history should be directly proportional to the teachers' professionalism. Villegas claimed that teacher learning activities enhance teacher professionalism, especially by enhancing teaching knowledge, skills and practice [7].

Another supporting factor for teacher professionalism is the active involvement of teachers in professional development. Teachers must constantly improve their competence through various efforts, including training, scientific writing activities, working group meetings and working deliberations through teacher working groups $(\mathrm{KKG})$. Teacher working group is a professional development activity that has been carried out in Indonesia to improve teacher professionalism [8].

In addition, increasing teacher professionalism must also be supported by the pedagogical competence of teachers. Pedagogic competence is the ability to manage student learning. Rahman stated that pedagogical competencies give possession effect to teacher performance [9]. Finally, based on the above background, the research is interested in proving whether the educational background, Teacher Working Group activities and teacher pedagogical competences strongly affect 
the professionalism of teachers. The difference with previous research is that in this study, the researcher tested collectively the effect of educational background variables, KKG activities and teacher pedagogical competence on teacher professionalism.

\section{METHODS}

This research was a correlational study with a quantitative approach. Broadly speaking, the purpose of this study is to explain whether or not there is an influence between educational background variables, Teacher Working Group activities and pedagogical competences on the professional competence of teacher.

Data collection was done by using a questionnaire or questionnaire technique. The population of this study were teachers in public elementary schools in Malang, as many as 53 teachers. Data analysis using multiple linear regression analysis. Hypothesis testing used partial significance test (ttest) with SPSS 22.0 for Windows.

\section{RESULTS AND DISCUSSION}

Based on the results of data analysis, the results of teacher education background were obtained. Table 1 below contains the results of the analysis of the teacher educational background variables $\left(\mathrm{X}_{1}\right)$.

TABLE I. EDUCATIONAL BACKGROUND QUESTIONNAIRE RESULTS

\begin{tabular}{|l|l|l|l|}
\hline Respondent Code & Score & \multicolumn{1}{|c|}{ Respondent Code } & Score \\
\hline R-1 & 3 & R-28 & 3 \\
\hline R-2 & 3 & R-29 & 3 \\
\hline R-3 & 3 & R-30 & 3 \\
\hline R-4 & 3 & R-31 & 3 \\
\hline R-5 & 3 & R-32 & 3 \\
\hline R-6 & 3 & R-33 & 3 \\
\hline R-7 & 3 & R-34 & 3 \\
\hline R-8 & 3 & R-35 & 3 \\
\hline R-9 & 3 & R-36 & 2 \\
\hline R-10 & 3 & R-37 & 3 \\
\hline R-11 & 2 & R-38 & 3 \\
\hline R-12 & 3 & R-39 & 3 \\
\hline R-13 & 3 & R-40 & 2 \\
\hline R-14 & 3 & R-41 & 3 \\
\hline R-15 & 3 & R-42 & 3 \\
\hline R-16 & 3 & R-43 & 3 \\
\hline R-17 & 3 & R-44 & 3 \\
\hline R-18 & 3 & R-45 & 3 \\
\hline R-19 & 3 & R-46 & 3 \\
\hline R-20 & 3 & R-47 & 3 \\
\hline R-21 & 3 & R-48 & 3 \\
\hline R-22 & 3 & R-49 & 3 \\
\hline R-23 & 2 & R-50 & 3 \\
\hline R-24 & 3 & R-51 & 3 \\
\hline R-25 & 3 & R-52 & 3 \\
\hline R-26 & 3 & R-53 & 3 \\
\hline R-27 & 3 & Score Average & $\mathbf{3}$ \\
\hline & & & \\
\hline
\end{tabular}

Furthermore, the criteria about the compliance level of teacher education backgrounds refer to the following Table 2 about the compliance level criteria.

TABLE II. COMPLIANCE LEVEL CRITERIA

\begin{tabular}{|l|l|l|}
\hline No. & \multicolumn{1}{|c|}{ Level of Conformity } & Score \\
\hline 1 & Very suitable & 4 \\
\hline $\mathbf{2}$ & Corresponding & $\mathbf{3}$ \\
\hline 3 & Not quite right & 2 \\
\hline 4 & It is not in accordance with & 1 \\
\hline
\end{tabular}

Based on the result average value of the educational background variable $\left(\mathrm{X}_{1}\right)$ as presented in Table 1 , the average value of teacher education background is 3 which is in the corresponding category because it located at the level of compliance number 2 in Table 2

Meanwhile the data analysis results of the KKG activity variables $\left(\mathrm{X}_{2}\right)$ are as presented in Table 3 below about the results of the KKG activity questionnaire.

TABLE III. RESULTS OF THE KKG ACTIVITY QUESTIONNAIRE

\begin{tabular}{|c|c|c|c|}
\hline Respondent Code & Score & Respondent Code & Score \\
\hline $\mathrm{R}-1$ & 4 & $\mathrm{R}-29$ & 3 \\
\hline $\mathrm{R}-2$ & 4 & R-30 & 4 \\
\hline R-3 & 4 & R-31 & 4 \\
\hline R-4 & 4 & R-32 & 3 \\
\hline R-5 & 3 & $\mathrm{R}-33$ & 4 \\
\hline R-6 & 4 & R-34 & 4 \\
\hline $\mathrm{R}-7$ & 4 & $\mathrm{R}-35$ & 3 \\
\hline $\mathrm{R}-8$ & 3 & R-36 & 4 \\
\hline R-9 & 3 & $\mathrm{R}-37$ & 4 \\
\hline $\mathrm{R}-10$ & 4 & $\mathrm{R}-38$ & 4 \\
\hline $\mathrm{R}-11$ & 4 & R-39 & 3 \\
\hline R-12 & 4 & $\mathrm{R}-40$ & 4 \\
\hline $\mathrm{R}-13$ & 4 & $\mathrm{R}-41$ & 4 \\
\hline $\mathrm{R}-15$ & 3 & $\mathrm{R}-42$ & 3 \\
\hline R-16 & 4 & $\mathrm{R}-43$ & 4 \\
\hline $\mathrm{R}-17$ & 3 & $\mathrm{R}-44$ & 4 \\
\hline $\mathrm{R}-18$ & 4 & $\mathrm{R}-45$ & 3 \\
\hline R-19 & 4 & R-46 & 4 \\
\hline $\mathrm{R}-20$ & 4 & $\mathrm{R}-47$ & 4 \\
\hline $\mathrm{R}-21$ & 4 & R-48 & 4 \\
\hline R-22 & 3 & R-49 & 4 \\
\hline R-23 & 4 & R-50 & 4 \\
\hline R-24 & 4 & R-51 & 4 \\
\hline R-25 & 3 & R-52 & 4 \\
\hline R-26 & 3 & R-53 & 4 \\
\hline R-27 & 3 & \multirow[t]{2}{*}{ Score Average } & \multirow[t]{2}{*}{4} \\
\hline R-28 & 3 & & \\
\hline
\end{tabular}

The criteria for the attendance category of the KKG refer to Table 4 below about the KKG attendance category criteria. 
TABLE IV. KKG ATTENDANCE CATEGORY CRITERIA

\begin{tabular}{|l|l|l|l|}
\hline No. & \multicolumn{1}{|c|}{ Criteria } & Attendance per year & Score \\
\hline 1 & Very Poor $(\mathrm{KS})$ & $1-2$ & 1 \\
\hline 2 & Poor $(\mathrm{K})$ & $3-4$ & 2 \\
\hline 3 & Good $(\mathrm{B})$ & $5-6$ & 3 \\
\hline $\mathbf{4}$ & Very Good (BS) & $\mathbf{7 - 8}$ & $\mathbf{4}$ \\
\hline
\end{tabular}

Based on the result average value of the $\mathrm{KKG}$ activity variable $\left(\mathrm{X}_{2}\right)$ as presented in Table 4 above, the average value of teacher attendance in KKG activities is 4 which is in the very good category (BS) because it is located at 7-8 attendance levels per year as explanation in Table 4 above.

The data analysis results of the teacher pedagogic competence variable $\left(\mathrm{X}_{3}\right)$ are as presented in Table 5 about the teacher pedagogic competency questionnaire results.

TABLE V. Teacher Pedagogic COMPETENCy Questionnaire RESULTS

\begin{tabular}{|l|l|l|l|}
\hline Respondent Code & Score & Respondent Code & Score \\
\hline R-1 & 3 & R-29 & 3 \\
\hline R-2 & 3 & R-30 & 3 \\
\hline R-3 & 3 & R-31 & 3 \\
\hline R-4 & 3 & R-32 & 3 \\
\hline R-5 & 3 & R-33 & 3 \\
\hline R-6 & 3 & R-34 & 3 \\
\hline R-7 & 3 & R-35 & 3 \\
\hline R-8 & 3 & R-36 & 3 \\
\hline R-9 & 3 & R-37 & 3 \\
\hline R-10 & 3 & R-38 & 3 \\
\hline R-11 & 3 & R-39 & 3 \\
\hline R-12 & 3 & R-40 & 3 \\
\hline R-13 & 3 & R-41 & 3 \\
\hline R-14 & 3 & R-42 & 3 \\
\hline R-15 & 3 & R-43 & 3 \\
\hline R-16 & 3 & R-44 & 3 \\
\hline R-17 & 3 & R-45 & 3 \\
\hline R-18 & 3 & R-46 & 3 \\
\hline R-19 & 3 & R-47 & 3 \\
\hline R-20 & 3 & R-48 & 3 \\
\hline R-21 & 3 & R-49 & 3 \\
\hline R-22 & 3 & R-50 & 3 \\
\hline R-23 & 3 & R-51 & 3 \\
\hline R-24 & 3 & R-52 & 3 \\
\hline R-25 & 3 & R-53 & 3 \\
\hline R-26 & 3 & Score Average & 3 \\
\hline R-27 & 3 & & \\
\hline R-28 & 3 & & \\
\hline & & & \\
\hline & & & 3 \\
\hline
\end{tabular}

Furthermore, the criteria about the compliance level of teacher pedagogical competencies refer to the following Table 6 about the compliance level criteria.
TABLE VI. COMPLIANCE LEVEL CRITERIA

\begin{tabular}{|l|l|l|}
\hline No. & \multicolumn{1}{|c|}{ Level of Conformity } & Score \\
\hline 1 & Very suitable & 4 \\
\hline $\mathbf{2}$ & Corresponding & $\mathbf{3}$ \\
\hline 3 & Not quite right & 2 \\
\hline 4 & It is not in accordance with & 1 \\
\hline
\end{tabular}

Based on the result average value of the teacher pedagogical competence variable $\left(\mathrm{X}_{3}\right)$ as presented in Table 5 above, the average value of teacher pedagogic competence is 3 which is included in the corresponding criteria because it located at the level of compliance number 2 as described in Table 6 above.

The results of regression analysis can be seen in Table 7 below about the results of multiple regression analysis, which is carried out for testing the research hypothesis.

TABLE VII. MultiPle REGRESSION ANALYSIS

\begin{tabular}{|c|c|c|c|c|c|c|c|}
\hline \multicolumn{8}{|c|}{ Coefficients $^{\mathrm{a}}$} \\
\hline \multirow{2}{*}{ Model } & \multicolumn{2}{|c|}{$\begin{array}{c}\text { Unstandardized } \\
\text { Coefficients }\end{array}$} & \multirow{2}{*}{\begin{tabular}{|c|}
$\begin{array}{c}\text { Standardized } \\
\text { Coefficients }\end{array}$ \\
Beta \\
\end{tabular}} & \multirow{2}{*}{$\mathbf{t}$} & \multirow{2}{*}{ Sig. } & \multicolumn{2}{|c|}{$\begin{array}{c}\text { Collinearity } \\
\text { Statistics } \\
\end{array}$} \\
\hline & $\boldsymbol{B}$ & Std. Error & & & & Tolerance & $V I F$ \\
\hline (Constant) & 3.425 & 2.083 & & 1.644 & .001 & & \\
\hline L.pddkn & .355 & .050 & .158 & 1.107 & .000 & .952 & 1.050 \\
\hline A.KKG & .288 & .045 & .026 & .387 & .000 & .998 & 1.002 \\
\hline Pedagogik & .339 & .010 & .131 & .917 & .000 & .953 & 1.049 \\
\hline
\end{tabular}

Based on the results of the above analysis, it can be seen that the independent variables have an effect on the dependent variable. The effect of the independent variable can be seen based on its accuracy or significance value. Therefore, the teacher background variable $\left(\mathrm{X}_{1}\right)$, teacher working group activity $\left(\mathrm{X}_{2}\right)$ and teacher pedagogical competence $\left(\mathrm{X}_{3}\right)$ have a significant positive effect on teacher professionalism $(\mathrm{Y})$. The following are the results of the t-test for each variable are presented in Table 8 .

TABLE VIII. T-Test Result (PARTIAL SignificAnCE Test)

\begin{tabular}{|l|c|c|l|}
\hline \multicolumn{1}{|c|}{ Variable } & t-test & Sig & Information \\
\hline Constant & 3,425 & 0.001 & Significant \\
\hline Education Backgroung $\left(\mathrm{X}_{1}\right)$ & 0,355 & 0.000 & Significant \\
\hline KKG Activities $\left(\mathrm{X}_{2}\right)$ & 0,288 & 0.000 & Significant \\
\hline Teacher Pedagogic Competensies $\left(\mathrm{X}_{3}\right)$ & 0,339 & 0,000 & Significant \\
\hline
\end{tabular}

Based on the t-test result as presented in Table 8 above, it can be seen that the results of the analysis of the 1st hypothesis resulted in a significance value of 0.000 with a t-count value of 0.355 . This shows that educational background $\left(\mathrm{X}_{1}\right)$ has a significant positive effect on teacher professionalism (Y). This means that the higher the level of education of a teacher affect the level of professionalism of the teacher. 
The results of the analysis of the second hypothesis resulted in a significance value of 0.000 with a t-count value of 0.2888 . This indicates that the Teacher Working Group activity $\left(\mathrm{X}_{2}\right)$ has a significant positive effect on teacher professionalism (Y). This means that the more often a teacher is present and active in Teacher Working Group activities also affect the level of teacher professionalism.

The results of the analysis of the third hypothesis resulted in a significance value of 0.000 with a t-count value of 0.339 . This shows that teacher pedagogical competence $\left(\mathrm{X}_{3}\right)$ has a significant positive effect on teacher professionalism (Y). This means that the higher the teacher's pedagogical competence affect the level of teacher professionalism.

Teachers as professional educators have a very strategic role in improving the quality of education. Teachers need to be continuously monitored for their professional abilities, because through continuous supervision they will constantly update their professional abilities. Teachers who have competence in learning will be more meaningful $[10,11]$. Therefore, it is very important for all teachers to continuously develop themselves and their competencies, particularly those related to the teaching process.

The existence of education, training and teaching experience has an important influence for teachers to improve their professionalism [12]. The experience of participating in training conducted by teachers to improve their competence and the educational background of the teacher has a more significant influence on teacher professionalism than the experience or length of teaching teachers [13]. A study concluded that teacher professionalism is one of the factors that influence students' problem-solving abilities [14]. Furthermore, Opolot's research also states that based on the results of his research, teacher professional factors greatly affect student achievement [15]. The implication of this research is that teachers should be given the widest possible opportunity to continue education and training that supports their professionalism in schools. This is because it is closely related to student achievement.

\section{CONCLUSION}

Based on the results of the data analysis and discussion above, it can be concluded that the professionalism of a teacher cannot be obtained just like that but must go through various efforts that must be made. This study proves that the level of educational background that teachers have has an effect on the level of teacher professionalism. Teachers who are active in Teacher Working Group activities also have an effect on the level of professionalism. Likewise, teacher pedagogical competence affects teacher professionalism. This study also found overall effect between educational background, teacher work group and pedagogic competence on teacher professionalism.

\section{ACKNOWLEDGMENT}

The author would like to thank those who have helped the smooth completion of this research article.

\section{REFERENCES}

[1] H. Tanang and B. Abu, "Teacher Professionalism and Professiona Development Practices in South Sulawesi, Indonesia," J. Curric. Teach., vol. 3, no. 2, pp. 25-42, 2014, doi: 10.5430/jct.v3n2p25.

[2] S.G. Rivkin, E.A. Hanushek, and J.F. Kain, "Teachers, Schools, and Academic Achievement," Econometrica. National Bureau of Economic Research, Cambridge, MA, 2005, doi: 10.1111/j.14680262.2005.00584.x

[3] M.S. Tichenor and J.M. Tichenor, "Understanding Teachers , Perspectives on Professionalism," Prof. Educ., vol. XXVII, no. 1, pp. 89-95, 2005.

[4] Human Development Report 2011. London: Routledge, 2011.

[5] T.W. Bank, "Transforming Indonesia 's Teaching Force," vol. II, p. $120,2010$.

[6] Ristekdikti, "Rencana Strategis 2015-2019," Jakarta, 2015.

[7] T.-J. Tsai and Y.-C. Shih, "Teacher Professional Development," in Professional Development and Workplace Learning, 2015, pp. 20452074, doi: 10.4018/978-1-4666-8632-8.ch112.

[8] W.M. Hapsariputri, “Evaluating Teachers ' Quality Improvement Policy in Indonesia Teachers ' Quality Improvement Policy in Indonesia To meet the UNESCO-EFA criteria," Delft University of Technology, 2010 .

[9] M.H. Rahman, "Professional Competence, Pedagogical Competence and the Performance of Junior High School of Sscience Teachers," J. Educ. Pract., vol. 5, no. 9, pp. 75-80, 2014

[10] Y. Wandasari, M. Kristiawan, and Y. Arafat, "Policy Evaluation of School's Literacy Movement on Improving Discipline of State High School Students,” Int. J. Sci. Technol. Res., vol. 8, no. 4, pp. 1-9, 2019.

[11] B. Lian, M. Kristiawan, and R. Fitriya, "Giving Creativity Room to Students Through the Friendly School's Program,” Int. J. Sci. Technol. Res., vol. 7, no. 7, pp. 1-11, 2018, doi: 10.31219/osf.io/zebpd.

[12] H. Irmayani, D. Wardiah, and M. Kristiawan., "The Strategy of SD Pusri in Improving Educational Quality,” Int. J. Sci. Technol. Res., vol. 7, no. 7, pp. 1-9, 2018.

[13] Y. Harisman, Y.S. Kusumah, K. Kusnandi, and M.S. Noto, "the Teachers' Experience Background and Their Profesionalism," Infin. J., vol. 8, no. 2, p. 129, 2019, doi: 10.22460/infinity.v8i2.p129-142.

[14] Y. Harisman, Y.S. Kusumah, and K. Kusnandi, "How Teacher Professionalism Influences Student Behaviour in Mathematical Problem-Solving Process," in Journal of Physics: Conference Series, 2019, p. 1188, doi: 10.1088/1742-6596/1188/1/012080.

[15] C. Opolot, "Improving Communication Skills in Science and Mathematics Education for Quality Student Outcomes.," 2014 